\title{
C-reactive protein levels in community-acquired pneumonia
}

\author{
E. García Vázquez*, J.A. Martínez*, J. Mensa*, F. Sánchez*, M.A. Marcos", A. de Roux", A. Torres"
}

C-reactive protein levels in community-acquired pneumonia. E. García Vázquez, J.A. Martínez, J. Mensa, F.Sánchez, M.A. Marcos, A.de Roux, A. Torres. (C)ERS Journals Ltd 2003.

ABSTRACT: The diagnostic value of $C$-reactive protein (CRP) admission serum levels as an indicator of the aetiology of community-acquired pneumonia (CAP) was evaluated.

A cohort of 1,222 patients with CAP was assessed. CRP levels were analysed in 258 patients with a single aetiological diagnosis.

The mean CRP values in patients with pyogenic, atypical, viral and Legionella pneumophila pneumonia were: $16 \mathrm{mg} \cdot \mathrm{dL}^{-1}, 13 \mathrm{mg} \cdot \mathrm{dL}^{-1}, 14 \mathrm{mg} \cdot \mathrm{dL}^{-1}$ and $25 \mathrm{mg} \cdot \mathrm{dL}^{-1}$, respectively. CRP levels were not significantly different among patients outcome research team (PORT) groups $\left(19 \mathrm{mg} \cdot \mathbf{d L}^{-1}\right.$ in groups $\mathrm{I}-\mathrm{II}, 16 \mathrm{mg} \cdot \mathrm{dL}^{-1}$ in group III and $16 \mathrm{mg} \cdot \mathrm{dL}^{-1}$ in groups IV-V. A cut-off point of $25 \mathrm{mg} \cdot \mathrm{dL}^{-1}$ had a sensibility, specificity, positive predictive value and negative predictive value of $0.6,0.83,0.3$, and 0.94 , respectively. After controlling for age and PORT score, the odds of having a CRP level $>25 \mathrm{mg} \cdot \mathrm{dL}^{-1}$ was 6.9 times higher in patients with $L$. pneumophila pneumonia than in those with non- $L$. pneumophila pneumonia.

Patients with Legionella pneumophila pneumonia had higher C-reactive protein levels than those with pneumonia of any other aetiology, independently of severity of infection. Being a cheap and readily available test, C-reactive protein may be a useful adjunctive procedure in the diagnosis of community-acquired pneumonia.

Eur Respir J 2003; 21: 702-705.
Depts of *Infectious Diseases, " Microbiology, Respiratory Diseases, Hospital Clinic, Barcelona, Spain.

Correspondence: E. García Vázquez

Servicio de Infecciones

Hospital Clínic

C/Villarroel 170

08036 Barcelona

Spain

Fax: 34934514438

E-mail: egarciav@clinic.ub.es

Keywords: Aetiology

C-reactive protein

community acquired pneumonia

diagnosis

Legionella pneumophila

Received: August 292002

Accepted after revision: October 242002
C-reactive protein (CRP) is an acute phase protein synthesised by hepatocytes. In response to infection or tissue inflammation, CRP production is rapidly stimulated by cytokines, particularly interleukin (IL)-6, IL-1 and tumour necrosis factor [1-3]. Although its exact function in vivo is not known, it probably has a role in opsonisation of infectious agents and damaged cells.

Two different uses of CRP have been investigated. Firstly, as a diagnostic tool to distinguish between noninfectious and infectious conditions and within the latter between viral and bacterial or superficial and deep infections $[1,2]$. CRP levels are usually lower in viral and superficial bacterial infections than in deep bacterial infections. Secondly, as a prognostic and follow-up test, as serial measurements may be useful to evaluate the response to antibiotic treatment and to detect complications in patients with infections $[1,2,4,5]$.

Several studies have corroborated the role of CRP in the diagnosis of bacterial versus viral meningitis [6] in children and suspected septicaemia in neonates $[2,7]$. However, its role in the aetiological diagnosis of respiratory infections is not well established. Usefulness of CRP to distinguish between bacterial and viral pneumonia or typical and atypical pneumonia has been previously analysed but data are discordant [8-10] and its value as a first-line method of screening remains inconclusive.

The aim of the present study was to evaluate the diagnostic value of CRP serum levels at admission as an indicator of the aetiology of community-acquired pneumonia (CAP).

\section{Patients and methods}

A total 1,222 consecutive patients aged $>14$ yrs with acute symptoms consistent with CAP were studied from October
1996-October 2000, according to a standard protocol in the Respiratory and Infectious Diseases Services at the Hospital Clínic in Barcelona (Spain), a 800-bed university teaching hospital.

CAP was defined as the presence of a new infiltrate on the chest radiograph along with appropriate clinical history and physical signs of lower respiratory tract infection in a patient not hospitalised within the previous month and in whom no alternative diagnosis emerged during follow-up. Clinical, laboratory and radiological features at presentation as well as other epidemiological data were recorded on a specific questionnaire and entered in a computer database. CAP severity was assessed within the first day of admission using patients outcome research team (PORT) score [11]. This study population has been previously described [12].

Patients with neutropenia $\left(<1.0 \times 10^{9} \cdot \mathrm{L}^{-1}\right)$, human immunodeficiency virus (HIV) infection, tuberculosis, fungal infection and those treated with steroids in a prednisone-equivalent dosage of $>20 \mathrm{mg} \cdot \mathrm{day}^{-1}$ for $\geqslant 2$ weeks were excluded.

\section{Microbiological evaluation}

At least one sputum sample, two blood cultures and two serum samples for serology (4-8 weeks apart) were obtained. Pleural puncture, transthoracic needle puncture, tracheobronchial aspiration (in mechanically ventilated patients) and protected specimen brush (PSB) or bronchoalveolar lavage (BAL) sampling were performed according to clinical indication or judgement of the attending physician.

Expectorated sputum samples were examined by Gram stain and accepted as suitable for culture if they satisfied the standard criteria of: 1$)<10$ squamous epithelial cells per 
low-power field; 2) >25 polymorphonuclear cells per lowpower field; and 3) presence of a predominant morphotype. Such validated sputum, blood culture samples, undiluted and serially diluted tracheobronchial aspirates (TBAS) and PSB and BAL fluid samples were plated on the following media: blood-sheep agar, chenodeoxycholate agar, chocolate agar and Sabouraud agar. Undiluted PSB and BAL fluid samples were also cultured on charcoal-yeast-extract agar. Identification of microorganisms was performed according to standard methods. Urine was collected in the acute phase for detection of soluble pneumococcal antigen by antibody assay (Binax $\mathbb{R}$ Streptococcus pneumoniae urinary antigen test; Binax, Portland, ME, USA) and Legionella pneumophila antigen by enzyme immunoassay (Bio Test $\mathbb{R}$ L. pneumoniae urinary antigen; Bio Test, Ciudad, Germany).

The aetiology of pneumonia was considered definitive if one of the following criteria was met: 1) blood cultures yielding a bacterial pathogen (in the absence of an apparent extrapulmonary focus); 2) pleural fluid or transthoracic needle aspiration cultures yielding a bacterial pathogen; 3 ) seroconversion (i.e. a four-fold increase in immunoglobulin (Ig)G titres for Chlamydia pneumoniae, C. psitacci, L. pneumophila, Coxiella burnetii and respiratory viruses (Influenza viruses $\mathrm{A}$ and $\mathrm{B}$, parainfluenza viruses $1-3$, respiratory syncytial virus and adenovirus); 4) a single IgM titre for $C$. pneumoniae $(\geqslant 1: 32)$, C. burnetii $(\geqslant 1: 80)$ and Mycoplasma pneumoniae (any titre); 5) a positive urinary antigen for $L$. pneumophila; 6) quantitative bacterial growth $\geqslant 10^{5}$ colony forming units (cfu) $\cdot \mathrm{mL}^{-1}$ in TBAS, $\geqslant 10^{3} \mathrm{cfu} \cdot \mathrm{mL}^{-1}$ in PSB and $\geqslant 10^{4} \mathrm{cfu} \cdot \mathrm{mL}^{-1}$ in BAL; 7) a positive urinary antigen for S. pneumoniae.

Serum samples were obtained within the first $24 \mathrm{~h}$ of admission to quantify CRP levels by using a commercially available kit (radial immunodiffusion). The normal reference range for the assay is $<0.1 \mathrm{mg} \cdot \mathrm{dL}^{-1}$.

The association of CRP with the aetiological diagnosis and the influence of putative confounders were explored by both stratified and multivariate analysis. The Pearson productmoment correlation parameter $(\mathrm{r})$ was calculated to measure correlation between CRP and age or PORT score. Means of CRP levels among different aetiological groups were compared by using two-tailed unpaired t-tests or analysis of the variance (ANOVA). Multivariate analysis was performed by using a stepwise nonconditional logistic regression procedure, considering age, PORT score and aetiological groups as independent variables and CRP $\left(>25 \mathrm{mg} \cdot \mathrm{dL}^{-1}\right.$ and $\leqslant 25 \mathrm{mg} \cdot \mathrm{dL}^{-1}$ ) as the dependent variable. Diagnostic parameters such as sensitivity, specificity and positive and negative predictive values were calculated according to standard equations.

\section{Results}

An aetiological diagnosis was achieved in 534 of 1,222 evaluated patients $(45 \%)$. One-hundred and thirty-six patients who had two aetiological diagnoses $(11 \%)$ were excluded from the analysis. Out of the remaining 398 patients with a single diagnosis only 258 had a CRP measurement within the first $24 \mathrm{~h}$ of admission and these constituted the study population. These CRP levels were available in 80 dual aetiology cases and in 383 CAP cases of unknown aetiology.

The mean \pm SD age of the 258 patients was $66 \pm 18.6 \mathrm{yrs}$ and 167 were male $(65 \%)$. Distribution of sex and ages was not different according to aetiology of pneumonia.

In the analysed cohort, the predominant pathogen was S. pneumoniae (80 cases, 31\%), followed by L. pneumophila (30 cases, 12\%) and Haemophilus influenzae (26 cases, 10\%).
An atypical bacterial pneumonia due to $C$. pneumoniae, C. psitacci, $M$. pneumoniae or $C$. burnetii was diagnosed in 52 patients $(20 \%)$ and a viral pneumonia in $35(14 \%)$.

Mean CRP levels according to aetiological diagnosis are shown in table 1. CRP values (mean) were significantly higher in patients with $L$. pneumophila $\left(25 \mathrm{mg} \cdot \mathrm{dL}^{-1}\right)$ than in those with pyogenic pneumonia $\left(16 \mathrm{mg} \cdot \mathrm{dL}^{-1}\right)$, viral pneumonia $\left(14 \mathrm{mg} \cdot \mathrm{dL}^{-1}\right)$ and atypical pneumonia $\left(13 \mathrm{mg} \cdot \mathrm{dL}^{-1}\right)(\mathrm{p}=$ $0.0002)$. When grouping the patients in those with $(n=30)$ and without $(\mathrm{n}=228)$ L. pneumophila pneumonia, the mean CRP values in the L. pneumophila group was still significantly higher than in the group with other diagnoses $\left(25 \mathrm{mg} \cdot \mathrm{dL}^{-1}\right.$ versus $\left.15 \mathrm{mg} \cdot \mathrm{dL}^{-1}, \mathrm{p}=0.0003\right)$. Mean CRP values were not significantly different among non- $L$. pneumophila diagnostic groups $(\mathrm{p}=0.24)$ or among those 80 patients with more than one pathogen identified or the 383 with CAP of unknown aetiology $(\mathrm{p}>0.05)$.

The mean number of days that patients were ill before admission was not significantly different in those with L. pneumophila pneumonia (5 days) and those with nonL. pneumophila pneumonia (5.4 days) $(\mathrm{p}=0.8)$.

CRP levels were not correlated with PORT score ( $\mathrm{r}=-0.04$; $\mathrm{p}=0.5)$ or age $(\mathrm{r}=0.05 ; \mathrm{p}=0.4)$ and accordingly, they were not significantly different among PORT groups $\left(19 \mathrm{mg} \cdot \mathrm{dL}^{-1}\right.$ in groups I-II, $16 \mathrm{mg} \cdot \mathrm{dL}^{-1}$ in group III and $16 \mathrm{mg} \cdot \mathrm{dL}^{-1}$ in groups $\mathrm{IV}-\mathrm{V}, \mathrm{p}=0.5)$ or between the elderly and younger patients $\left(16 \mathrm{mg} \cdot \mathrm{dL}^{-1}\right.$ in patients aged $<65 \mathrm{yrs}(\mathrm{n}=95)$ and $16 \mathrm{mg} \cdot \mathrm{dL}^{-1}$ in patients aged $\left.\geqslant 65 \mathrm{yrs}(\mathrm{n}=163) ; \mathrm{p}=0.85\right)$. On the other hand, although age was not significantly different among aetiological categories $(\mathrm{p}=0.21)$, mean PORT scores among aetiological groups were different by ANOVA analysis $(\mathrm{p}=0.02)$. This was apparently due to the fact that patients with L. pneumophila pneumonia had slightly less severe pneumonia than patients with pyogenic pneumonia (mean PORT score $91(\mathrm{p}<0.05)$ versus $110(\mathrm{p}>0.1)$, respectively, by pair-wise analysis with Bonferroni correction).

According to a receiver operator curve, a cut-off point of 25 appeared to be the best CRP value for the diagnosis of L. pneumophila pneumonia. A CRP level $>25 \mathrm{mg} \cdot \mathrm{dL}^{-1}$ had a

Table 1.-C-reactive protein (CRP) levels and aetiological diagnosis

\begin{tabular}{lcc}
\hline Agent & $\begin{array}{c}\text { Patients } \\
\mathrm{n}\end{array}$ & $\begin{array}{c}\mathrm{CRP} \text { mean } \\
\mathrm{mg} \cdot \mathrm{dL}^{-1}\end{array}$ \\
\hline Typical bacterial pneumonia & 141 & 16 \\
Streptococcus pneumoniae & 80 & 17.15 \\
Haemophilus influenzae & 26 & 12.93 \\
Other & 35 & 15.6 \\
Legionella pneumophila pneumonia & 30 & 25.23 \\
Atypical pneumonia & 52 & 12.64 \\
Chlamydia pneumoniae & 20 & 11.74 \\
Mycoplasma pneumoniae & 17 & 16.02 \\
Coxiella burnetii & 15 & 10.02 \\
Viral & 35 & 14.45 \\
Total & 258 & 16.18 \\
Patients with >1 pathogen identified & 80 & \\
Pyogenic pneumonia & 38 & 18.82 \\
Pyogenic pneumonia+Legionella & 2 & 14.9 \\
Pyogenic pneumonia+atypical bacteria & 12 & 13.8 \\
Pyogenic pneumonia+viral & 17 & 16.76 \\
Viral pneumonia+Legionella & 1 & 33.98 \\
Viral pneumonia+atypical bacteria & 6 & 12.9 \\
Atypical pneumonia+Legionella & 4 & 27.03 \\
CAP of unknown aetiology & 383 & 14.01 \\
\hline
\end{tabular}

CAP: community-acquired pneumonia. ${ }^{*}:>1$ microorganism isolated; ${ }^{\uparrow}$ : not included in statistical analyses due to the small number of cases. 
sensibility, specificity, positive predictive value and negative predictive value of $0.6,0.83,0.3$, and 0.94 , respectively.

As expected, logistic regression analysis confirmed that high CRP values were independently associated with $L$. pneumophila aetiology. After controlling for age and PORT score, the odds that patients with $L$. pneumophila pneumonia had a CRP level $>25 \mathrm{mg} \cdot \mathrm{dL}^{-1}$ were 6.9 times higher than that of patients with non-L. pneumophila pneumonia $(95 \%$ confidence interval (CI) 3.02-15.8; $\mathrm{p}<0.0001) ; 5.7$ times higher than those with pyogenic pneumonia (95\% CI 2.4-13.6; $\mathrm{p}<0.0001)$; 13 times higher than those with atypical pneumonia (95\% CI 3.6-47.7; $<<0.0001)$; and 7.8 times higher than those with viral pneumonia $(95 \% \mathrm{CI}$ 2-29.6; $\mathrm{p}=0.002$ ) (table 2).

\section{Discussion}

Early and appropriate treatment of CAP patients is one of the most important factors to reduce morbidity and mortality [13]. A causative agent is seldom identified in $>50-70 \%$ of cases, $S$. pneumoniae being the most common pathogen. Pneumonia due to $C$. burnetii, $C$. psitacci, $C$. pneumoniae, $M$. pneumoniae and respiratory viruses is usually mild, though $L$. pneumophila pneumonia may be severe and its detection can be of epidemiological importance. Regarding the aetiological diagnosis of pneumonia, clinical and chest radiographical findings lack accuracy [14, 15] cultures take at least $24 \mathrm{~h}$ to produce a positive result and specific rapid tests based on the detection of soluble antigens of $S$. pneumoniae or L. pneumophila in body fluids are not always available. Therefore, initial antibiotic therapy is usually chosen on an empirical basis [16].

The role of CRP as a tool in the diagnostic work-up of patients with lung infiltrates of presumed infectious aetiology remains controversial [8-10]. ADNET et al. [17] showed that high CRP levels were helpful in the diagnosis of bacterial pneumonia secondary to aspiration in patients with druginduced coma and pulmonary infiltrates, in whom other parameters such as fever and white blood cell counts were of poor sensitivity and specificity. PÖNKA and SARNA [18] and ÖRQVIST et al. [19] showed that pneumonias caused by $S$. pneumoniae, especially when bacteraemic, were associated with a greater host response (higher levels of IL-6 and CRP) than those caused by other pathogens (M. pneumoniae and viruses). LEHTOMÄKI [20] found that higher CRP values distinguished pneumococcal pneumonia from other pneumonias $\left(16 \mathrm{mg} \cdot \mathrm{dL}^{-1}\right.$ in the former versus $5 \mathrm{mg} \cdot \mathrm{dL}^{-1}$ in adenoviral pneumonia, $6 \mathrm{mg} \cdot \mathrm{dL}^{-1}$ in mycoplasmal pneumonia; $\left.\mathrm{p}<0.001\right)$. Some [21, 22] but not all studies [8, 23], pointed out that CRP had among other markers of inflammatory response the

Table 2.-C-reactive protein (CRP) levels and aetiological diagnosis: multivariate analysis

\begin{tabular}{lccc}
\hline Agent & $\mathrm{OR}^{\#}$ & $95 \% \mathrm{CI}$ & $\mathrm{p}$-value \\
\hline $\begin{array}{l}\text { L. pneumophila } \\
\text { pneumonia/pyogenic pneumonia }\end{array}$ & 5.7 & $2.4-13.6$ & $<0.0001$ \\
$\begin{array}{l}\text { L. pneumophila } \\
\text { pneumonia/atypical pneumonia }\end{array}$ & 13 & $3.6-47.7$ & $<0.0001$ \\
$\begin{array}{l}\text { L. pneumophila } \\
\text { pneumonia/viral pneumonia }\end{array}$ & 7.8 & $2.0-29.0$ & $<0.01$ \\
$\begin{array}{l}\text { L. pneumophila } \\
\text { pneumonia/non-L. pneumophila } \\
\text { pneumonia }\end{array}$ & 6.9 & $3.02-15.8$ & $<0.0001$ \\
\hline
\end{tabular}

L. pneumophila: Legionella pneumophila; \#: for CRP $>25 \mathrm{mg} \cdot \mathrm{dL}^{-1}$; CI: confidence interval; OR: odds ratio. best predictive value to distinguish viral from bacterial pneumonia.

In the present series, CRP levels in patients with a viral diagnosis were not significantly different from those of patient with pyogenic or non- $L$. pneumophila, nonviral atypical pneumonia. The present data referring to patients with viral pneumonia showed that mean CRP concentrations $\left(14 \mathrm{mg} \cdot \mathrm{dL}^{-1}\right)$ were higher than those observed in children $\left(2.6-5.4 \mathrm{mg} \cdot \mathrm{dL}^{-1}\right)[24,25]$ but of the same range as those reported both in children with viral plus bacterial superinfection $\left(9.5 \mathrm{mg} \cdot \mathrm{dL}^{-1}\right)$ [26] and in hospitalised adults with influenza $\left(12.3 \mathrm{mg} \cdot \mathrm{dL}^{-1}\right)$ [27]. The authors believe that the most plausible interpretation of this high CRP value in patients with a sole viral diagnosis is that they actually had secondary but nondocumented bacterial infection [28].

The present data show that CRP levels in patients with L. pneumophila pneumonia are higher than in those with CAP of any other aetiology, independently of potential confounders such as age and severity of illness. To the best of the authors' knowledge, this association has not been previously reported and raises the question of whether L. pneumophila triggers more (or different) inflammatory pathways than other atypical microorganisms. The production patterns of cytokines and acute-phase proteins are not similar in different inflammatory conditions. It has been speculated that in lung infections, damage in proximity to pulmonary circulation produces an immunological stimulus to hepatic CRP synthesis [1-7]. The greater the lung damage, the higher the CRP levels. The role of the inflammatory response in the pathogenesis of $L$. pneumophila pneumonia compared to that of pneumonias caused by other atypical agents should be further investigated, since the identification of important pathogenic factors could possibly provide alternative means for intervention in an entity that remains a potential fatal disease. Both duration of infection and antibiotic treatment can influence CRP results. It is known that radiological chest infiltrates in patients with $L$. pneumophila infection may worsen after the first dose of antibiotics, probably due to a Jarisch-Herxheimer-like reaction [29]. It could be that as part of this reaction, CRP levels also increase. Therefore, CRP concentrations previous to antibiotic therapy should be considered in order to accurately assess the relationship between CRP levels and L. pneumophila pneumonia. This was a limitation of the present study, because CRP was measured within the first $24 \mathrm{~h}$ of admission and not necessarily before the administration of the first antibiotic dose.

Despite the association of high CRP levels with L. pneumophila pneumonia, a satisfactory cut-off point to fulfil the positive predictive requirements for a useful diagnostic test at the prevalence of disease observed in this study, could not be found. However, with the current sensitivity and specificity of a CRP level $>25 \mathrm{mg} \cdot \mathrm{dL}^{-1}$, the positive predictive value could reach $77 \%$ at a prevalence of L. pneumophila pneumonia of $50 \%$. Therefore, it is predictable that in an epidemic situation, CRP can be a cheap and readily available test for the presumptive identification of case patients, particularly in settings where other rapid diagnostic tests such as those aimed at the detection of urinary antigen are not available. Conversely, the data show that CRP can be very useful to rule out $L$. pneumophila pneumonia (negative predictive value of $94 \%$ ), even at a disease prevalence typical of an endemic situation. It is recognised, however, that the availability of any diagnostic test aimed at the presumptive diagnosis of L. pneumophila pneumonia may be less of a need if, as recommended, a macrolide is systematically included as part of the empirical regimen given to patients with CAP who require hospitalisation or if a new quinolone is chosen as a single therapy. The recommendation of including a macrolide is based not only on the frequency of atypical microorganisms 
as causal agents of CAP, but also on the evidence that patients with pneumococcal pneumonia do better with a $\beta$-lactam-macrolide combination than with a $\beta$-lactam alone $[13,30]$. Nevertheless, given the known antagonism of macrolides on the in vitro antimicrobial activity of $\beta$-lactams against $S$. pneumoniae [31], the putative beneficial effect of a $\beta$-lactam-macrolide combination in patients with pneumococcal pneumonia should be confirmed, ideally in the setting of a clinical trial.

To conclude, the data suggest that $L$. pneumophila leads the inflammatory host response in a different way to other intracellular organisms and that $\mathrm{C}$-reactive protein may aid physicians to rule out $L$. pneumophila pneumonia.

\section{References}

1. Clyne B, Olshaker JS. The C-reactive protein. J Emergency Medicine 1999; 6: 1019-1025.

2. Hansson LO, Lindquist L. C-reactive protein: its role in the diagnosis and follow-up of infectious diseases. Current Opinion Infectious Diseases 1997; 10: 196-201.

3. Epstein F. Acute phase proteins and other systemic responses to inflammation. N Engl J Med 1999; 340: 448454.

4. Hansson LO, Hedlund JU, Ortqvist AB. Sequential changes of inflammatory and nutritional markers in patients with community-acquired pneumonia. Scand J Clin Lab Invest 1997; 57: 111-118.

5. Hedlund J. Community-acquired pneumonia requiring hospitalisation. Factors of importance for the short and long term prognosis. Scand J Infect Dis Suppl 1995; 97: 1-60.

6. Pedrazzi AHP. Acute phase proteins: clinical and laboratory diagnosis. A review. Ann pharmaceutiques françaises 1998; 56: $108-114$.

7. Peltola H, Jaakkola M. Serious bacterial infections: C-reactive protein as a serial index of severity. Clin Pediatr 1988; 27: 532-537.

8. Korppi M, Heiskanen-Kosma T, Leinonen M. White blood cells, C-reactive protein and erythrocyte sedimentation rate in pneumococcal pneumonia in children. Eur Respir J 1997; 10: $1125-1129$.

9. Smith RP, Lipworth BJ. C-reactive protein in simple community-acquired pneumonia. Chest 1995; 107: 1028-1031.

10. Smith RP, Lipworth B, Cree IA, Spiers EM, Winter JH. $\mathrm{C}$-reactive protein: a clinical marker in community-acquired pneumonia. Chest 1995; 108: 1288-1291.

11. Fine MJ, Auble TE, Yealy DM, et al. A prediction rule to identify low-risk patients with community acquired pneumonia. N Engl J Med 1997; 336: 243-250.

12. Ruiz M, Ewig S, Marcos MA, et al. Etiology of CommunityAcquired Pneumonia: impact of age, comorbidity and severity. Am J Respir Crit Care Med 1999; 160: 397-405.

13. Gleason PP, Meehan TP, Fine JM, Galusha DH, Fine MJ. Associations between initial antimicrobial therapy and medical outcomes for hospitalized elderly patients with pneumonia. Arch Intern Med 1999; 159: 2562-2567.

14. Holmberg H, Bodin L, Jonsson I, Krook A. Rapid aetiological diagnosis of pneumonia based on routine laboratory features. Scand J Infect Dis 1990; 22: 537-545.

15. Sopena $\mathrm{N}$, Sabrià-Leal $\mathrm{M}$, Pedro-Botet $\mathrm{ML}$, et al.
Comparative study of the clinical presentation of Legionella pneumonia and other community-acquired pneumonias. Chest 1998; 113: 1195-200.

16. Woodhead MA, McFarlane JT. Comparative clinical and laboratory features of legionella with pneumococcal and mycoplasma pneumonias. Br J Dis Chest 1987; 81: 133-139.

17. Adnet F, Borron SW, Vicaut E, et al. Value of C-reactive protein in the detection of bacterial contamination at the time of presentation in drug-induced aspiration pneumonia. Chest 1997; 112: 466-471.

18. Pönka A, Sarna S. Differential diagnosis of viral, mycoplasmal and bactaraemic pneumonias on admission to hospital. Eur J Respir Dis 1983; 4: 360-368.

19. Ortqvist A, Hedlund J, Wretlind B, Carlstrom A, Kalin M. Diagnostic and prognostic value of interleukin-6 and C-reactive protein in community-acquired pneumonia. Scand J Infect Dis 1995; 27: 457-462.

20. Lehtomäki K. Clinical diagnosis of pneumococcal, adenoviral, mycoplasma and mixed pneumonias in young men. Eur Respir J 1988; 1: 324-329.

21. Kerttula Y, Leinonen M, Koskela M, Mäkela PH. The aetiology of pneumonia. Application of bacterial serology and basic laboratory methods. J Infect 1987; 14: 21-30.

22. Peltola H, Räsänen JA. Quantitative C-reactive protein in relation to erythrocyte sedimentation rate, fever and duration of antimicrobial therapy in bacteremic diseases of childhood. J Infect 1982; 5: 257-267.

23. McCarthy PL, Frank AL, Ablow RC, et al. Value of the $\mathrm{C}$-reactive protein in the differentiation of bacterial and viral pneumonia. J Paediatr 1978; 92: $454-456$.

24. Heiskanen-Kosma T, Korppi M. Serum C-reactive protein cannot differentiate bacterial and viral aetiology of communityacquired pneumonia in children in primary healthcare settings. Scand J Infect Dis 2000; 32: 399-402.

25. Toikka P, Irjala K, Juven $\mathrm{T}$, et al. Serum procalcitonin, C-reactive protein and interleukin-6 for distinguishing bacterial and viral pneumonia in children. Pediatr Infect Dis J 2000; 19: 598-602.

26. Moulin F, Raymond J, Lorrot M, et al. Procalcitonin in children admitted to hospital with community acquired pneumonia. Arch Dis Child 2000; 84: 332-366.

27. Falsey A, Walsh E, Francis C, Looney J, Kolassa J, Hall W, Abraham G. Response of C-Reactive Protein and Serum Amyloid A to Influenza A infection in older adults. JID 2001; 183: 995-999.

28. Ruiz González: Is Streptococcus pneumoniae the leading cause of pneumonia of unknown etiology? A microbiologic study of lung aspirates in consecutive patients with community-acquired pneumonia. Am J Med 1999; 106: 385-390.

29. Macfarlane JT, Miller AC, Roderick-Smith WH, et al. Comparative radiographic features of community acquired Legionnaires' disease, pneumococcal pneumonia, mycoplasma pneumonia and psittacosis. Thorax 1984; 39: 28-33.

30. Sthal JE, Barza M, DesJardin J, Martin R, Eckman MH. Effect of macrolides as part of initial empiric therapy on length of stay in patients hospitalized with communityacquired pneumonia. Arch Intern Med 1999; 159: 2576-2580.

31. Johansen HK, Jensen TG, Dessau RB, Lundgren B, Frimodt-Moller N. Antagonism between penicillin and erythromycin against Streptococcus pneumoniae in vitro and in vivo. J Antimicrob Chemother 2000; 46: 973-980. 